\title{
Oil Palm Empty Fruit Bunch as a Potential Feedstock for Composting
}

\author{
Paridah Md Tahir ${ }^{1 \mathbb{C}}$, Ang Aik Fei ${ }^{2 \mathbb{D}}$, Zaidon Ashaari ${ }^{2 \mathbb{D}}$, Seng Hua Lee ${ }^{1, * \mathbb{D}}$, Syeed SaifulAzry Osman \\ Al-Edrus 1 (i) \\ 1 Institute of Tropical Forestry and Forest Products (INTROP), Universiti Putra Malaysia, 43400 UPM Serdang, Selangor, \\ Malaysia \\ 2 Faculty of Forestry and Environment, Universiti Putra Malaysia, 43400 UPM Serdang, Selangor, Malaysia \\ * Correspondence: lee_seng @upm.edu.my (S.H.L.);
}

Scopus Author ID 57191711306

Received: 29.08.2021; Revised: 10.10.2021; Accepted: 15.10.2021; Published: 30.10.2021

Abstract: Oil palm plantation has been widely planted in tropical countries, particularly Malaysia. Oil palm biomasses as by-products of palm oil production, therefore, exist abundantly. Four kilograms of dry biomasses are generated for every kilogram of palm oil produced. Empty fruit bunch is a major solid waste produced by palm oil mills, constituting $23 \%$ of the total weight of the fresh palm fruit bunch. As one of the largest palm oil producers, Malaysia generated a huge amount of EFB annually, making the country's disposal process a headache issue. Therefore, utilizing these wastes strategically could be beneficial from both economic and environmental points of view. Ideally, EFB could be used as feedstocks for bioenergy production, composites fabrication, activated carbon, and chemical synthesis. Apart from that, composting is also one of the potential approaches to solving this waste's abundance. Composting oil palm EFB means converting the EFB waste, which is essentially organic in nature, into humus suitable for crop production. The main purpose of composting is to handle organic wastes and enhance soil fertility safely. This paper gives an overview of the latest status and technologies dealing with composting of oil palm EFB, its limitations, current issues, and way forward.

Keywords: empty fruit bunch; enzymatic process; biomass; composting; feedstocks.

(C) 2021 by the authors. This article is an open-access article distributed under the terms and conditions of the Creative Commons Attribution (CC BY) license (https://creativecommons.org/licenses/by/4.0/).

\section{Introduction}

Oil palm tree (Elaeis guineensis) is common palm species native to west and southwest Africa. In only a few decades, oil palm trees have transformed from a small-scale plantation crop in Africa into the most profit-making agricultural commodities worldwide, particularly in South East Asia. In 2016, both Indonesia and Malaysia were the major producers of palm oil, where both countries account for $85 \%$ (approximately 49.56 million tons) of the world's palm oil output [1].

The productivity of palm oil per hectare is much higher than the productivity of soybean oil per hectare; the global production of palm oil is recorded as 58.31 million tonnes with an estimation of oil palm planting at 12.82 million hectares, while the global production of soybean oil is only 40.22 million tonnes with soybean planting at 104.55 million hectares. As a perennial crop, the long productive life span (25 years) of oil palm is another privilege over those annual oil crops, which have to be planted on a year-to-year basis. These facts revealed that oil palm is much more competitive than the other oil crops due to its very productive characteristic in nature, producing 3 to 8 times more oil per hectare than other oil crops [2]. 


\subsection{Availability of Empty Fruit Bunch (EFB).}

In the oil palm industry, both the fields and palm oil mills generated plenty of oil palm biomass, such as fronds, oil palm trunks, mesocarpfiber, empty fruit bunches, palm shells, and effluent. Due to the many recent advances in research and technological innovations, these oil palm biomasses have strategically turned into feedstocks for multiple ends uses ranging from wood-based products such as lumber, plywood, particleboard, fibreboard, pulp, and paper) to biochemicals and bioenergy.

Four kilograms of dry biomass are generated for every kilogram of palm oil produced. These biomasses comprise empty fruit bunch, oil palm trunks, and fronds [3]. According to Kassim et al. [4] and Kheang et al. [5], oil palm EFB is generated in the palm oil mills during the processing of fresh fruit bunch (FFB). It constituted approximately $23 \%$ of the weight of the FFB. Disposal of EFB is a major issue in palm oil mills for Malaysia as it is one of the world's largest producers of palm oil. Every year, around 50 million tonnes of dry oil palm residues are generated. The amount is expected to gain 2 -folds by 2020 [6]. For instance, some of this renewable lignocellulosic material is used for organic fertilizer and soil cover materials for the plants, while the rest of this solid waste is dumped in areas adjacent to the mill [7]. Due to its biorenewable and readily available, EFB is the potential to be used as feedstock for other useful applications so that the disposal and environmental issues in palm oil mills can be mitigated.

\subsection{Composting of EFB.}

Composting is among the potential approaches in solving the abundance of these wastes. Composting of oil palm EFB is means to convert the essentially organic EFB waste into humus suitable for crop production $[8,9]$. The higher plant material, a complex organic, degrades to simpler elements rich in organic nutrients under the stimulus of aerobic thermophilic microorganisms present in the EFB waste during the composting process. The main purpose of composting is to handle organic wastes and enhance soil fertility safely. Researchers have indicated that wastes from the palm oil industry are one of the most promising agricultural waste sources to be used as organic fertilizers.

According to Then et al. [10], several palm oil mills in Malaysia are now practicing bioconversion of EFB into compost in their waste management system to mitigate the disposal issue of this waste and return the nutrients to the plant nutrient cycle. Management of EFB waste through composting is a better method as composting offers several advantages. The advantages include lower cost, friendly to the environment, sustainability, reducing greenhouse gas emissions, and improving material recycling.

This paper gives an overview of the latest status and technologies dealing with composting of oil palm EFB, its limitations, current issues, and way forward.

\subsection{Palm oil production process.}

Two oil types are produced from the fresh oil palm fruits, e.g., palm oil from the fibrous mesocarp and lauric oil from the palm kernel. 


\section{EFB - A By-product from Palm Oil Mills}

In Malaysia, although the palm oil industry is a key industry for national income and economic expansion, it also imparts negative effects to the environment. Both the input and output sides of activities in this industry contribute to environmental degradation. On the input side, emission of greenhouse gases during the transportation of FFB from estates to the crude palm oil mills; consumption of the huge amount of water and energy in the production process in mills. On the other hand, wastewater, solid waste, and polluted air were generated during the manufacturing processes as output [11].

Apart from this, the palm oil industry is also a land-intensive industry [12]. Any unplanned exploration of lands to establish oil palm plantations will cause the forest systems to be degraded. Consequently, the habitats for flora and fauna are destroyed. On the other hand, applying herbicides and pesticides to maintain the plantations also causes water and air pollution problems.

EFB is the most generated solid wastes from palm oil mills [13]. EFB generated from the threshing process possesses high moisture content, approximately 60-70\%; this inhibits the possibility of EFB being used as fuel for power boilers [7]. Nonetheless, despite EFB being the most abundantly available solid waste generated in palm oil mills, its current utilization as feedstock for other end uses is rather limited. For instance, only a small amount is used as fertilizers and soil cover materials (mulching mats) in palm oil plantation areas. Due to the high transportation cost and logistic convenience, in some areas, the EFB is just dumped in areas adjacent to the mill [7]. However, burned EFB can be adopted as fertilizer by mulching in plantations because burned EFB could generate potash [13].

According to Siddiqui et al. [14], the gradual accumulation or incorrect disposal of EFB may cause environmental problems (e.g., disease inocula, homes for pests, etc.). On the other hand, Stichnothe and Schuchardt [15] reported that improper handling with the disposal of EFB causes e considerable environmental burdens, particularly greenhouse gas emissions.

Traditionally, palm oil mills' usual practice to deal with the disposal of EFB is burnt in simple incinerations and their ash recycled into the plantation as fertilizer [12]. However, this practice causes air pollution and has been banned by the authorities. In addition, combustion of EFB also causes severe slagging and fouling on the boiler heat-transfer surfaces due to the condensation and deposition of substances evolving from alkali metal forming ash on the lowtemperature surfaces [16-19].

Furthermore, this practice also wasted the EFB, which, as a renewable and abundantly available organic material, could have been used as feedstock for other value-added applications, such as converting it into bioenergy [20, 21], green composites [22-23], preparation of activated carbon to remove harmful substances [24, 25], production of chemical precursors [26, 27], and fertilizer enriched compost [14, 28]. This application will be discussed thoroughly in Section 4.0.

\section{EFB as a Potential Feedstock for another End Uses}

The building block of native EFB fiber comprises a complex matrix of three main polymers: cellulose, hemicellulose, and lignin. It is composed of approximately around $47.6 \%$ cellulose, $28.1 \%$ hemicellulose, and $13.1 \%$ lignin [29]. It also reported that EFB is composed $32.9 \%$ glucan, 22.4\% xylan and $1.4 \%$ arabinan [30]. Cellulose and hemicellulose can be hydrolyzed chemically by acid or enzymatically into glucose and various pentose and hexose 
sugars, which can then be fermented to produce bioethanol. In contrast, lignin can be modified chemically or biologically into low molecular weight phenolic compounds to generate various useful biochemicals.

\subsection{EFB for bioenergy production.}

As mentioned earlier, EFB can serve as a good feedstock for another application attributed to its sustainability and lignocellulosic nature. Due to these reasons, using EFB as feedstock to produce bioenergy as a substitution for non-renewable fossil fuels and thus help mitigate greenhouse gas emissions is possible. Furthermore, EFB is considered a good feedstock for producing second-generation bioenergy, as this biomass is not an edible food for humans. Studies have shown that the bioethanol production process from $\mathrm{NaOH}$ pre-treated EFB was effective, and it may be feasible for the high production of bioethanol of this waste in the near future [20].

In addition, Mohammed et al. [21] utilized EFB as feedstock to produce bio-oil, which later could be upgraded as biofuel. The EFB was saccharified into bio-oil using a green extraction method known as supercritical fluid extraction with supercritical $\mathrm{CO}_{2}$. Results showed that hexadecanoic acid (palmitic acid, $\mathrm{C}_{16}$ ), dodecanoic acid 1, 2, 3-propanetriyl ester (glycerol trilaurate, $\mathrm{C}_{39}$ ), and 6 octadecanoic acid (stearic acid, $\mathrm{C}_{18: 0}$ ) were identified as the major compounds.

A group of researchers had produced anhydrous ethanol using EFB in a pilot plant [31]. This study indicated that using an automatically controlled integrated process, the ethanol conversion rate, distillation, and dehydration efficiency were high $(83.6 \%, 98.9 \%$, and $99.2 \%$, respectively). As a result, $123.6 \mathrm{~kg}$ anhydrous ethanol (99.7 $\mathrm{wt} \%$ ) was possible to generate from $1000 \mathrm{~kg}$ EFB.

\subsection{EFB for composites production.}

$\mathrm{EFB}$ is a lignocellulosic material that has potential as a natural fiber resource. It can serve as an alternative raw material supply to substitute wood to produce composites since the current wood supply has become lesser. Moshiul Alam et al. [22] fabricated polylactic acid and oil palm empty fruit bunch fiber-reinforced green composites through extrusion followed by injection molding. The authors found that $30-\mathrm{mm}$ long and $40 \mathrm{wt} \%$ empty fruit bunch fiberincorporated composites show the optimum tensile strength and modulus. Compared to untreated fiber-reinforced composites, simultaneous ultrasound and alkali-treated empty fruit bunch-reinforced composites exhibited enhanced mechanical performances, crystallinity, thermal stability, and durability against fungi degradation.

EFB has been used as a fiber resource to fabricate eco-composite boards with 500, 600, and $700 \mathrm{~kg} / \mathrm{m}^{3}$ densities using 10,12, and $14 \%$ urea-formaldehyde resin as a binder [23]. The authors reported that the density of boards and amount of resin used to affect the overall performance of boards, and they concluded that the performance of the boards having a density of $700 \mathrm{~kg} / \mathrm{m}^{3}$ density bonded with $14 \%$ resin content is excellent accompanied by superior dimensional stability.

Research has been carried out to develop EFB and seaweed composite for soil erosion mitigation [32]. This study revealed that alkaline pre-treated EFB and seaweed composite can be applied as a soil stabilizer. It exhibits higher thickness swelling percentage and is sustained 
longer during water immersion than non-treated composite due to the better interface adhesion between EFB fiber and seaweed.

\subsection{EFB for activated carbon.}

EFB is suitable to be used as raw material for activated carbon production due to its high carbon content. Conversion of EFB to activated carbon offers some advantages, such as this could directly solve part of the environmental problem while offering better handling of this abundant and cheap solid waste to serve as a substitute to costly activated carbon.

Alam et al. [24] studied the suitability of activated carbons derived from EFB to remove heavy metal (Zinc) through the adsorption process. The authors found that activated carbon derived from $1000^{\circ} \mathrm{C}$ and 30 minutes has the maximum adsorption capacity $(1.63 \mathrm{mg} / \mathrm{g})$ to remove zinc $(98 \%)$ in the aqueous solutions.

Hameed et al. [25] studied the preparation of activated carbon from EFB through optimization using response surface methodology (RSM) for removal of 2,4,6-TCP. The authors reported that the outcomes under the optimum preparation conditions were $168.89 \mathrm{mg} / \mathrm{g}$ of 2,4,6-TCP uptake and $17.96 \%$ of activated carbon yield. Another study revealed that the activated carbon derived from EFB shows the capability to absorb trace elements such as arsenic and cadmium in contaminated soil [33]. The result showed that the maximum adsorption capacity $\left(\mathrm{q}_{\max }\right.$ ) of EFB activated carbon for arsenic and cadmium was 0.4240 and $15.1515 \mathrm{mg} \mathrm{g}^{-1}$, respectively.

\subsection{EFB as chemical feedstocks.}

Due to the constituents of EFB (cellulose, hemicellulose, and lignin), it could be used as feedstock in biorefinery so that palm oil production would become more environmentally friendly while maximizing profitability. Useful chemicals were extracted from EFB through the solvolysis process using different solvents such as acetone, ethylene glycol (EG), ethanol, water, and toluene [26]. The results showed that these solvents successfully extracted phenolic compounds, alcohol compounds, ketone, and aldehyde compounds from the EFB.

Tang et al. [27] used lignin which is derived from EFB, to produce useful chemicals that can be used for another application in the chemical industry. Hydroxybenzoic acid, phydroxybenzaldehyde, vanillic acid, vanillin, syringic acid, syringaldehyde, p-coumaric acid, ferulic acid are some of the chemicals that were successfully extracted from the EFB lignin in this study.

Medina et al. [34] validated that lignin-derived from EFB exhibits antioxidant capacity as they detected aromatic compounds were present in EFB lignin. Due to this feature, lignin presented promising antimicrobial properties. Furthermore, the authors also reported that lignin possesses $\alpha$-amylase inhibition properties that enable lignin to be used as a potential source of precursor drugs for the treatment of diabetes.

\section{EFB in Composting}

This section extensively discusses the methods of EFB composting, which cover the conventional and modified methods. Many studies have reported that composting is timeconsuming. The average time to produce good quality compost for EFB ranged from 12 to 300 days. Table 1 summarizes the methods used for EFB composting since the year of 1995. Different organic N-rich sources, such as goats, cattle, and chickens' manure, have always been 
used as $\mathrm{N}$ additives for the composting of EFB [13]. In the field of composting, C:N ratio is important to determine the state of composting. Compost scientists have determined that the $\mathrm{C}: \mathrm{N}$ ratio of 25-30:1 is the mature state of the compost [35].

Table 1. The conventional and current methods used for EFB composting.

\begin{tabular}{|c|c|c|c|c|}
\hline Ref. & Method & $\begin{array}{l}\text { Composting } \\
\text { Period }\end{array}$ & Disadvantages & Advantages \\
\hline [36] & $\begin{array}{l}\text { Inhabiting microorganism }+ \\
\text { supplement (cow dung }+ \\
\text { chicken manure }+ \text { goat } \\
\text { dung) }\end{array}$ & $\begin{array}{l}60 \text { days (Cow } \\
\text { dung; Initial } C: N \\
47: 1 \text {; final } C: N \\
12: 1)\end{array}$ & $\begin{array}{l}\text { > Bad odors } \\
\text { >Long composting } \\
\text { time >Not hygienic }\end{array}$ & $\begin{array}{l}\text { >Increasing EFB compost } \\
\text { yield and quality (Nitrogen } \\
\text { content) }\end{array}$ \\
\hline [37] & $\begin{array}{l}\text { Natural degradation (Open } \\
\text { environment; mulching) }\end{array}$ & $\begin{array}{l}10 \text { months } \\
\text { (Weigh of EFB; } \\
100 \% \text { dgradation) }\end{array}$ & $\begin{array}{l}>\text { Long } \\
\text { time }>\text { composting } \\
\text { and transportation } \\
\text { costs } \\
\text { by the rest oil (about } \\
1.25 \%) \\
\text { Attract beetles and snakes }\end{array}$ & $>$ Without supplement \\
\hline [38] & $\begin{array}{l}\text { Inhabiting microorganism + } \\
\text { supplement POME and } \\
\text { liquid fermentation wastes } \\
\text { from the food processing } \\
\text { industry (New fermentation } \\
\text { method) }\end{array}$ & $\begin{array}{l}52 \text { days (Open; } \\
\text { Initial } \mathrm{C}: \mathrm{N} 41: 1 \text {; } \\
\text { final } \mathrm{C}: \mathrm{N} 16: 1)\end{array}$ & $\begin{array}{l}>\text { No reports on inhabiting } \\
\text { microorganism }\end{array}$ & $\begin{array}{l}\text { >An opening composting } \\
\text { system is better than the } \\
\text { closed system }\end{array}$ \\
\hline [39] & $\begin{array}{l}\text { EFB + POME; Natural } \\
\text { degradation } \\
\text { environment; Wet tropical) }\end{array}$ & $\begin{array}{l}12 \text { weeks (Initial } \\
\text { C:N 50:1; final } \\
\text { C:N 15:1) }\end{array}$ & $\begin{array}{l}>\text { No reports on inhabiting } \\
\text { microorganism }\end{array}$ & $\begin{array}{l}\text { >Highlight the importance } \\
\text { of moisture content during } \\
\text { composting process }\end{array}$ \\
\hline [41] & 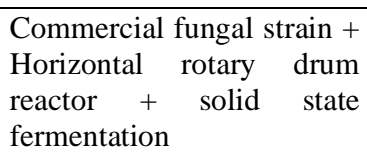 & $\begin{array}{l}60 \text { days (Initial } \\
\mathrm{C}: \mathrm{N} \text { 63:1; final } \\
\mathrm{C}: \mathrm{N} 17: 1)\end{array}$ & $\begin{array}{lr}>\text { Require } & \text { specific } \\
\text { equipment } & > \\
\text { Costly } & \end{array}$ & $\begin{array}{l}>\text { Microorganism grow in } \\
\text { agitation }\end{array}$ \\
\hline [42] & $\begin{array}{l}\text { Natural compost } \\
\text { Trichoderma harzianum }\end{array}+$ & 5 weeks & $>$ No report on $\mathrm{C}: \mathrm{N}$ ratio & $\begin{array}{ll}>\text { Using } & \text { specific } \\
\text { microorganism } & \end{array}$ \\
\hline [51] & $\begin{array}{lr}\text { Natural compost } & + \\
\text { supplement } & \text { (open } \\
\text { environment) } & \end{array}$ & 300 days & $\begin{array}{l}>\text { Bad } \\
\text { odors } \\
\text { composting time }\end{array}$ & \\
\hline [40] & $\begin{array}{l}\text { EFB + POME; Natural } \\
\text { degradation } \\
\text { environment; Wet tropical) }\end{array}$ & $\begin{array}{l}20 \text { weeks (Initial } \\
\text { C:N 50:1; final } \\
\text { C:N 30:1) }\end{array}$ & $\begin{array}{l}>\text { No reports on inhabiting } \\
\text { microorganism } \\
>\text { Low temperature } \\
23^{\circ} \mathrm{C} \quad>\text { High Moisture }\end{array}$ & $\begin{array}{l}>\text { Highlight the importance } \\
\text { of moisture content during } \\
\text { composting process }\end{array}$ \\
\hline [52] & $\begin{array}{l}\text { Inhabiting bacteria + POME } \\
\text { anaerobic sludge }+ \text { open } \\
\text { method (under shade and } \\
\text { cement base) Brick size } \\
2.1 \mathrm{~m} \times 1.5 \mathrm{~m} \times 1.5 \mathrm{~m}\end{array}$ & $\begin{array}{l}40 \text { days (Initial } \\
C: N \text { 44.5:1; final } \\
C: N \text { 12.8:1) }\end{array}$ & $\begin{array}{l}\text { >Inconsistent } \\
\text { quality > Uncontrolled } \\
\text { microorganism interactions. }\end{array}$ & $\begin{array}{l}\text { >Open air composting } \\
\text { better than closed } \\
\text { system >Partially reacted } \\
\text { POME (supplement) is } \\
\text { proved can be used as } \\
\text { microbial seedling. }\end{array}$ \\
\hline [43] & $\begin{array}{l}\text { Natural compost }+ \text { decanter } \\
\text { cake slurry (regular turning } \\
\text { plant) }\end{array}$ & $\begin{array}{l}>51 \text { days (Initial } \\
\text { C:N 63.67; final } \\
C: N 18.65: 1 \text { ) }\end{array}$ & $\begin{array}{l}>\text { No report on microbial } \\
\text { composition }\end{array}$ & $\begin{array}{l}\text { >Decanter cake slurry } \\
\text { improved degradation of } \\
\text { EFB. }\end{array}$ \\
\hline [44] & $\begin{array}{lr}\text { Commercial } & \begin{array}{r}\text { microbial } \\
\text { activators }\end{array} \\
\text { decomposer } & \text { fungi } \\
\text { (Corynascus } & \text { sp., } \\
\text { Scytalidum } & s p . \text {, } \\
\text { Chaetomium } & s p . \text {, } \\
\text { Scopulariopsis } & \text { sp., } \\
\text { Streptomyces sp.), alcoholic } \\
\text { yeast (Saccharomyces sp.), } \\
\text { and bacteria (Bacillus sp., } \\
\text { Lactobacillus sp.) }+ \\
\text { supplement } & \text { (decanter } \\
\text { sludege) compares with }\end{array}$ & $\begin{array}{l}>60 \text { days; aerobic } \\
>90 \quad \text { days; } \\
\text { anaerobic }\end{array}$ & $\begin{array}{l}\text { >Used microorganism } \\
\text { activator } \\
>\text { Costly }\end{array}$ & $\begin{array}{l}>\text { Replacement chicken } \\
\text { manure to decanter sludge } \\
\text { to improve odor problem. }\end{array}$ \\
\hline
\end{tabular}




\begin{tabular}{|c|c|c|c|c|}
\hline Ref. & Method & $\begin{array}{l}\text { Composting } \\
\text { Period }\end{array}$ & Disadvantages & Advantages \\
\hline & $\begin{array}{l}\text { chicken manre. Method: } \\
\text { Anaerobic \& aerobic }\end{array}$ & & & \\
\hline [45] & $\begin{array}{l}\text { Commercial fungi } \\
\text { (Trichoderma virens) }+ \\
\text { POME supplement }\end{array}$ & 92 days & $\begin{array}{lr}>\text { Using only } & 1 \\
\text { microorganism } & \text { as } \\
\text { degradation agent } & \end{array}$ & $\begin{array}{l}>\text { Microbial } \\
\text { approach >Cheap } \\
\text { (only } 1 \text { microorganism) }\end{array}$ \\
\hline [46] & $\begin{array}{l}\text { Inhabiting bacteria + POME } \\
\text { anaerobic sludge + open } \\
\text { method Method: In-vessel } \\
\text { composter }\end{array}$ & $\begin{array}{l}40 \text { days (Initial } \\
\mathrm{C}: \mathrm{N} \text { 58:1; final } \\
\mathrm{C}: \mathrm{N} 13.85: 1 \text { ) }\end{array}$ & $>$ Costly & $\begin{array}{l}\text { >Systematic composting } \\
\text { plan }\end{array}$ \\
\hline [47] & $\begin{array}{l}\text { Commercial } \\
\text { (Trichoderma } \\
\text { viride F26, Trichoderma } \\
\text { reesei RUT C-30, Panus } \\
\text { tigrinus } \\
\text { M609RQY (IMI 398363) } \\
\text { and Penicillium sp.,) + } \\
\text { POME supplement } \\
\text { Method: Tray and covered } \\
\text { by aluminum foil. }\end{array}$ & 60 days & $\begin{array}{l}>\text { Usage of Penicillium sp. at } \\
\text { the end-stage might } \\
\text { contribute to antibiotic } \\
\text { resistance. }\end{array}$ & $\begin{array}{l}\text { >Used fungi for other } \\
\text { enzymatic applications } \\
\text { (such as used for ethanol, } \\
\text { pulp, paper and etc. }\end{array}$ \\
\hline [48] & $\begin{array}{l}\text { Commercial fungi } \\
\text { (Trichoderma virens, } \\
\text { Trichoderma reesei and } \\
\text { Aspergillus niger) + POME } \\
\text { supplement }\end{array}$ & 36 days & $\begin{array}{l}\text { >Treated EFB with a } \\
\text { chemical for lignin removal }\end{array}$ & $\begin{array}{l}\text { >Used fungi for other } \\
\text { enzymatic applications } \\
\text { (such as used for ethanol, } \\
\text { pulp, paper and etc. }\end{array}$ \\
\hline [49] & Natural compost + POME & $\begin{array}{l}12 \text { days (Initial } \\
C: N \text { 45:1) }\end{array}$ & $\begin{array}{l}>\text { Final } \mathrm{C}: \mathrm{N} \text { ratio is not } \\
\text { measured }\end{array}$ & $\begin{array}{l}\text { >Methane production is } \\
\text { positively correlated to the } \\
\text { degradation of the compost } \\
\text { >Effect of different CN } \\
\text { ratios towards the } \\
\text { biodegradability of POME } \\
\text { and EFB is investigated }\end{array}$ \\
\hline [50] & $\begin{array}{lr}\text { Natural compost }+ \\
\text { Trichoderma } & \text { Selective } \\
\text { Medium isolate } & \end{array}$ & $\begin{array}{l}28 \text { days (Initial } \\
\mathrm{C}: \mathrm{N} \text { 10.42:1; final } \\
\mathrm{C}: \mathrm{N} 2.79: 1\end{array}$ & $\begin{array}{l}\text { >Identity of the fungi only } \\
\text { up to genus level }\end{array}$ & $\begin{array}{l}>\text { Microbial approach } \\
>\text { Cheap (only } \\
\text { microorganism) }\end{array}$ \\
\hline
\end{tabular}

In 1995, Thambirajah et al. [36] composted EFB and EFB supplemented with either goat dung, chicken manure, or cow dung, which resulted in different $\mathrm{C}: \mathrm{N}$ ratios after 60 days of composting. Significant reduction of the initial C:N ratios $(52: 1,35: 1,48: 1,47: 1)$ for the four compost to $\mathrm{C}: \mathrm{N}$ ratios of $24: 1,14: 1,18: 1$ and 12:1, respectively, were observed. Both mesophilic and thermophilic bacteria showed consistent activity throughout the process, whereas fungal activity was completely suppressed during the peak heating phase $\left(70^{\circ} \mathrm{C}\right)$. The finding demonstrated that the rate of cellulosic material utilization is positively correlated with the increase of nitrogen content in the compost [36].

The decomposition of EFB in oil palm plantations has been done by Hamdan and Mohammed Mohd Tayeb [37]. In the field study, the EFB was spread in the field as a mulch on top of a nylon net at a rate of 30,60, and $90 \mathrm{mt} / \mathrm{ha} /$ year. Every 2 months before fresh EFB application, spots were selected to ensure a $\mathrm{C} / \mathrm{N}$ ratio of 15,30 , and 60 was achieved. 
Estimation of decomposition was made by calculating the remaining weight of EFB in the nylon net. After 10 months, the EFB was completely decomposed. The method requires a longer composting period, yet it is eco-friendly without the usage of supplementation.

One of the studies compared the effect between open and closed EFB composting systems [38]. In the study, mixtures of EFB, fermentation liquid waste (POME), and chicken manure were the raw composting materials. Aeration is ensured by the porous nature of the material itself and further improved by mechanical turning equipment. The composting process is faster in the open system compared to the closed system. To achieve the C:N ratio of 16, the closed system required 85 days, while the open system only required 50 days. However, the researchers did not report on the inhabiting microorganism during the composting process.

The composting of EFB from oil palms has been carried out under a wet tropical climate at Medan in Indonesia by Schuchardt et al. [39]. Fresh POME was added to replace moisture loss due to the high rate of water evaporation during the composting process and followed by homogeneously mixing and aerating the composting ingredients with a self-driving windrow turning machine. The $\mathrm{C}: \mathrm{N}$ ratio of 50 was reduced to 15 after 12 weeks of the rotting process. In comparison to the results of Schuchardt et al. [39], another study done in the province of Izabal, Guatemala showed abundant rainfall significantly $(p<0.05)$ slowed down the composting process, lengthening the active period phase to 20 weeks [40]. The temperature in Guatemala was lower, and the moisture level was higher compared to Indonesia, where the average air temperature was $23.1^{\circ} \mathrm{C}$, and annual rainfall has been up to 3,600 $\mathrm{mm}$ in Guatemala. The slow composting could be due to the nonequilibrium temperature distribution from the slowdown of air circulation by high moisture level.

A new composting trial was carried out in 2007 where POME and EFB were mixed with the induced microorganisms to overcome a conventional composting process [41]. The composting process uses selected substrates, POME, and EFB plus wheat flour as a cosubstrate in a tray bio-reactor. The process involved using fungi isolates from POME such as strains of Penicillium sp., Phanerochaete chrysosporium, Trichoderma harzianum, and Aspergillus niger (A 106, S 101). The resulting C:N ratio dropped to 17 from 63 after 2 months period. Inoculating the specific microorganism into EFB oil palm compost has also been done by Siddiqui et al. [42] using T. harzianum. Trichoderma-enriched EFB extracts showed significant $(\mathrm{p}<0.05)$ higher degradation compared to the uninoculated EFB sample.

Another study by Yahya et al. [43] successfully converted EFB with an initial C:N ratio 63.67:1 to final compost with $\mathrm{C}: \mathrm{N}$ ratio of 18.65:1 in 51 days. Yahya and colleagues studied the interaction of EFB and decanter cake slurry (by adding POME) in a commercial composting plant with regular turning operation. The composting process of the EFB was boosted by the presence of decanter cake slurry. After 51 days, the $\mathrm{C}: \mathrm{N}$ ratio of the mature compost with the decanter cake slurry was only $18.65: 1$, while without the presence of decanter cake slurry, the ratio stayed high at 28.96:1. Besides, Kananam et al. [44] found that the use of decanter sludge did not affect any biochemical conditions of EFB composting. The final composting product met the compost nutrient standard where the $\mathrm{C}: \mathrm{N}$ ratio is 15:1 within 30 days. However, under anaerobic conditions, the composting process failed to complete on day $90^{\text {th }}$. The results highlighted the importance of aeration during the degradation process and the aerobic nature of the composting bacteria and fungi.

Trichoderma virens have been used solely as an activator to convert EFB and POME into compost [45]. Compost with supplementation of both $T$. virens and organic $\mathrm{N}$ (chicken manure) has a higher biodegradation rate than compost with EFB and POME alone. Besides, 
higher xylanase and cellulase activities from $T$. virens resulted in rapid degradation of both cellulose and hemicelluloses.

Using a newly developed method, Razali et al. [46] investigated the alteration of the lignocellulosic structure of EFB during composting in an in-vessel composter. A total of 40 days was required for the composting treatment to reduce the initial $\mathrm{C}: \mathrm{N}$ ratio of 58:1 to 13.85:1. The peak of degradation occurred during the thermophilic phase, as shown by scanning electron microscopy analysis. As expected, the in-vessel composter significantly ( $p<0.05)$ improved the composting of EFB, yet the method is expensive thus impractical in the industrial field.

Chai et al. [28] suggested that the impropriate $\mathrm{C} / \mathrm{N}$ ratio is the main reason that $\mathrm{EFB}$ is unable to be composted solely. They suggest that composting of EFB becomes more effective when using a co-composting method where other organic waste materials with a $\mathrm{C} / \mathrm{N}$ ratio of less than 30 can be mixed with EFB as a nitrogen source in the co-composting. Based on their point of view, a mixing percentage of $50 \%$ to $60 \%$ of EFB is deemed an ideal ratio in EFB cocomposting.

An effective composting process of EFB with POME, using a multi-enzymatic fungal system, had been developed by Mohammad et al. [47]. Four strains of filamentous fungi, namely Trichoderma viride F26, Trichoderma reesei RUT C-30, Panus tigrinus M609RQY (IMI 398363), and Penicillium sp., were selected in this study. A higher decrement of C:N ratio was achieved in the fungal treated system, in which the reduction was almost double compared to the control after 60 days. In addition, high activity of ligninase enzyme and cellulase activity was found in the system. Yet, the presence of Penicillium sp. in the compost may create an antibiotic resistance problem.

Another study was done by Amira et al. [48], where EFB and POME were used as substrates for compost production using fungi. Activators such as Trichoderma virens, Trichoderma reesei, and Aspergillus niger were employed to enhance the biodegradation process. As previously mentioned, enhanced degradation of cellulose and hemicellulose within 36 days could be achieved with the incorporation of fungi due to higher xylanase and cellulase activity. Trichoderma virens yielded the highest xylanase activity compared to control. Aspergillus niger, on the other hand, has the highest number of activities of filter paper unit (FPU). The drawback of the study was the use of chemicals to remove lignin, which may pose a risk to plant health when used in fertilizer.

Nurliyana et al. [49] investigated the effect of different $\mathrm{C}: \mathrm{N}$ ratios towards the codigestion of POME and EFB in terms of the biodegradability of the substrates. The $\mathrm{C}: \mathrm{N}$ ratios were adjusted to a specific value by using different EFB and POME loadings. The degradation rate of co-digestion of POME with EFB was evaluated through methane production and was found to be positively correlated to the degradation of organic substrates. The results demonstrated that the $\mathrm{C}: \mathrm{N}$ ratio of 45 (EFB:POME; 76:24) has the highest biodegradability rate in POME and EFB.

In 2017, Trichoderma sp. from soil was selected for composting of EFB using Trichoderma Selective Medium [50]. The initial C:N ratio of 10.42:1 was observed to decrease to a final C:N ratio of 2.79:1. Although the composting method in the study was conducted using the microbial approach, fungi's identity is not specified to species level. 


\section{Issues and Challenges in EFB Composting}

Although composing seems to offer a better solution for EFB waste, some barriers impede EFB waste composting. Broadly, the challenges that persist in the oil palm industries themselves include acceptance and participation, administrative, management, logistical, technological, marketing, and demand [53]. The application of composting technology is generally new for some oil palm mills. This renders delays for the implementation of such technology due to a shortage of experienced and skilled workers.

On the other hand, the development of the composting technology at the oil palm mill faces various issues. The issues in composting technology include source separation, composting process, contamination, quality of the end product (nutrient content and moisture), and effective composting technologies [54-59]. The composting process requires to prolong period, which is impractical for industrial purposes. The characteristics of EFB in nature make it difficult to be composted alone because microorganisms are difficult to grow on it as this organic waste is classified as carbon source material and has lower moisture and nitrogen contents [28-29]. EFB also had very low bulk density $\left(66.98 \mathrm{~kg} / \mathrm{m}^{3}\right)$, which the heat during composting may be difficult to retain if the open windrows method is used [28]. Due to EFB being a by-product from palm oil production, residual palm oil was found to range from 3 to $7 \%$ on a dry basis [60]. Residual oil in EFB will slow down the decomposition process and may attract pests and vermin.

As EFB possess some limitations to be composted alone, to reduce the composting period, selection of the most suitable enzymes or microorganisms for composting plant is crucial [61]. Besides, the pungent smell resulting from the composting process is one of the main issues in the industry [62].

\section{Way Forward}

As the palm oil industry will remain one of the key industries for national income generation and economic expansion, the generation of EFB as the most abundant solid waste in palm oil mills will not end. Therefore, the disposal issue of EFB is always a challenge in the palm oil industry [63]. Converting EFB to other value-added applications is a promising way to handle the disposal issue of EFB while creating some value-added applications from this readily available, abundant, biodegradable, and cheap organic waste material [64-65].

Therefore, it is proposed that the optimum condition for composting should be focused on the following criteria: the moisture level, $\mathrm{C}: \mathrm{N}$ ratio, aeration, etc. As discussed in Section 4.0, when compared to conventional methods, current methods emphasize using certain strains of fungi to reduce the composting time, produce high-quality compost, solve environmental problems, and enhance economic benefits in the oil palm industry.

The government encouraged the practice of converting oil palm wastes such as EFB into value-added applications (e.g., bio-fertilizer) through the introduction of the National Agro-Food Policy (2011-2020) and the National Biomass Strategy 2020. Incentives such as Depreciation Accelerated Capital Allowance will be given to palm oil mills to procure machinery required for converting oil palm wastes into value-added products such as fertilizer, animal feed, and biogas. Apart from this, palm oil mills will also be entitled to income tax exemption (ranging from 30 to $100 \%$ ) if they produce promoted products (e.g., palm-based bio-fertilizer) or engage in such activities. 
However, additional efforts should be executed by the government. The government should formulate the Oil Palm Biomass Policy or Roadmap and proper management on the distribution of biomass amongst sectors (wood-based, bio-fuel, bio-fertilizer, or bio-based chemicals). In addition, setting up a biomass consortium or Biomass Collection center is also an important move. Apart from that, the government should establish certification and controls on the quality of products to ensure compliance with international standards by relevant parties. More funding should also be allocated to support pilot or demo plants study and support the industry by engaging the stakeholders.

\section{Funding}

This research was funded by MINISTRY OF HIGHER EDUCATION, MALAYSIA, grant number 5540158, Reference code: FRGS/1/2018/WAB07/UPM//1.

\section{Acknowledgments}

The authors would like to express their gratitude to all the lab officers from the Institute of Tropical Forestry and Forest Product, Universiti Putra Malaysia, for assisting with the project.

\section{Conflicts of Interest}

The authors declare no conflict of interest.

\section{References}

1. Aznam Shah, S. Challenges for Malaysia's commodities. Available from https://bepi.mpob.gov.my/news/detail.php?id=26761. 2018.

2. Barcelos, E.; Rios, S.D.A.; Cunha, R.N.; Lopes, R.; Motoike, S.Y.; Babiychuk, E.; Skirycz, A.; Kushnir, S. Oil palm natural diversity and the potential for yield improvement. Front. Plant Sci. 2015, 6, 190. https://doi.org/10.3389/fpls.2015.00190

3. Kurnia, J.C.; Jangam, S.V.; Akhtar, S.; Sasmito, A.P.; Mujumdar, A.S. Advances in biofuel production from oil palm and palm oil processing wastes: A review. Biofuel Res J 2016, 9, 332-346, https://doi.org/10.18331/BRJ2016.3.1.3.

4. Kassim, M.A.; Bakar N.A.; Kheang, L.S.; Aziz, A. Influence of solid loading concentration, inoculums size and nitrogen sources on ethanol production from empty fruit bunches (EFB) hydrolysate in separate hydrolysis and fermentation (SHF). Res J Appl Sci 2011, 6, 310-319, https://doi.org/10.3923/rjasci.2011.310.319.

5. Kheang, L.S.; Subramaniam, V.; Ngatiman, M. Oil Palm Biomass Energy Resource Data. Malaysia Palm Oil Board, Bangi 2012.

6. Agensi Innovasi Malaysia.: National Biomass Strategy 2020: New Wealth Creation for Malaysia's Biomass Industry. AIM, Cyberjaya 2013.

7. Paepatung, N.; Nopharatana, A.; Songkasiri, W. Bio-methane potential of biological solid materials and agricultural wastes. As J Energy Env 2009, 10, 19-27.

8. Gomez, R.J.H.C.; Park, Y.K. Conversion of cane bagasse to compost and its chemical characteristics. $J$ Ferment Technol 1983, 61, 329-332.

9. Gray, K. R.; Sherman, K.; Biddlestone, A.J. A review of composting. Part I. Microbiology and biochemistry. Process Biochem 1971, 6, 32-36.

10.Then, K.H.; Sarmidi, M.R.; Alwee, S.S.S.R.; Zakaria, Z.A. Recycling of oil palm empty fruit bunch as potential carrier for biofertilizer formulation. Jurnal Teknologi 2016, 78, 165-170, https://doi.org/10.11113/jt.v78.7375.

11. Chavalparit, O.; Rulkens, W.H.; Mol, A.P.J.; Khaodhair, S. Options for environmental sustainability of the crude palm oil industry in Thailand through enhancement of industrial ecosystems. Environ Dev Sustain 2006, 8, 271-287, https://doi.org/10.1007/s10668-005-9018-z.

12. Abdullah, N.; Sulaiman, F. The oil palm wastes in Malaysia. In: Matovic, M.D. (ed.) Biomass Now Sustainable Growth and Use 2013, 75-93. IntechOpen, London.

13. Singh, R.; Ibrahim, M.H.; Esa, N.; Iliyana, M. Composting of waste from palm oil mill: a sustainable waste management practice. Rev Environ Sci Bio 2010, 9, 331-344, https://doi.org/10.1007/s11157-010-9199-2. 
14. Siddiqui, Y.; Meon, S.; Mohd, S.I.; Rahmani, M.; Ali, A. Efficient conversion of empty fruit bunch of oil palm into fertilzer enriched compost. Asian J Microbiol Biotechnol Environ Sci 2009, 11, 1-6.

15. Stichnothe, H.; Schuchardt, F. Life cycle assessment of two palm oil production systems. Biomass Bioenerg 2011, 35, 3976-3984, https://doi.org/10.1016/j.biombioe.2011.06.001.

16. Abdullah, N.; Sulaiman, F.; Gerhauser, H. Characterisation of oil palm empty fruit bunches for fuel application. J Phys Sci. 2011, 22, 1-24.

17. Konsomboon, S.; Pipatmanomai, S.; Madhiyanon, T.; and Tia, S. Effect of kaolin addition on ash characteristics of palm empty fruit bunch (EFB) upon combustion. Appl Energy 2011, 88, 298, https://doi.org/10.1016/j.apenergy.2010.07.008.

18. Madhiyanon, T.; Sathitruangsak, P.; Sungworagarn, S.; Pipatmanomai, S.; Tia, S. A pilot-scale investigation of ash and deposition formation during oil-palm empty-fruit-bunch (EFB) combustion. Fuel Process Technol 2012, 96, 250-264, https://doi.org/10.1016/j.fuproc.2011.12.020.

19. Madhiyanon, T.; Sathitruangsak, P.; Sungworagarn, S.; Fukuda, S.; Tia, S. Ash and deposit characteristics from oil-palm empty-fruit-bunch (EFB) firing with kaolin additive in a pilot-scale grate-fired combustor. Fuel Process Technol 2013, 115, 182-191, https://doi.org/10.1016/j.fuproc.2013.05.018.

20. Sudiyani, Y.; Styarini, D.; Triwahyuni, E.; Sudiyarmanto, Sembiring, K.C.; Aristiawan, Y.; Abimanyu, H.; Han, M.H. Utilization of biomass waste empty fruit bunch fiber of palm oil for bioethanol production using pilot-scale unit. Energy Procedia 2013, 32, 31-38, https://doi.org/10.1016/j.egypro.2013.05.005.

21. Mohammed, Y.S.; Mokhtar, A.S.; Bashir, N.; Saidur, R. An overview of agricultural biomass for decentralized rural energy in Ghana. Renew Sustain Energy Rev 2013, 20, 15-25, https://doi.org/10.1016/j.rser.2012.11.047.

22. Moshiul Alam, A.K.M.; Beg, M.D.H.; Mina, M.F.; Mamun, A.A.; Bledzki, A.K. Degradation and stability of green composites fabricated from oil palm empty fruit bunch fiber and polylactic acid: Effect of fiber length. J Compos Mater 2014, 49, 3103-3114, https://doi.org/10.1177/0021998314560219.

23. Wahab, R.; Mat Rasat, Md. S.; Samsi, H.W.; Mustafa, Md. T.; Mohd. Don. S.M. Assessing the suitability of agro-waste from oil palm empty fruit bunches as quality eco-composite boards. J Agric Sci 2017, 9, 237-247, https://doi.org/10.5539/jas.v9n8p237.

24. Alam, M.Z.; Muyibi, S.A.; Kamaldin, N. Production of activated carbon from oil palm empty fruit bunches for removal of zinc. In: Twelfth International Water Technology Conference, IWTC12 2008 Alexandria, Egypt 2008, 373-384.

25. Hameed, B.H.; Tan, I.A.W.; Ahmad, A.L. Preparation of oil palm empty fruit bunch-based activated carbon for removal of 2,4,6-trichlorophenol: Optimization using response surface methodology. J Hazard Mater 2009, 164, 1316-1324, https://doi.org/10.1016/j.jhazmat.2008.09.042.

26. Fan, S.P.; Zakaria, S.; Chia, C.H.; Jamaluddin, F.; Nabihah, S.; Liew, T.K.; Pua, F.L. Comparative studies of products obtained from solvolysis liquefaction of oil palm empty fruit bunch fibres using different solvents. Bioresour Technol 2011, 102, 3521-3526, https://doi.org/10.1016/j.biortech.2010.11.046.

27. Tang, P.L.; Hassan, O.; Maskat, M.Y.; Badri, K. Production of monomeric aromatic compounds from oil palm empty fruit bunch fiber lignin by chemical and enzymatic methods. Biomed Res Int 2015, 2015, 891539, https://doi.org/10.1155/2015/891539.

28. Chai, E.W.; H’ng, P.S.; Peng, S.H.; Wan-Azha, W.M.; Chin, K.L.; Chow, M.J.; Wong, W.Z. Compost feedstock characteristics and ratio modelling for organic waste materials co-composting in Malaysia. Environ Technol 2013, 34, 2859-2866, https://doi.org/10.1080/09593330.2013.795988.

29. Baharuddin, A.S.; Sulaiman, A.; Kim, D.H.; Mokhtar, M.N.; Hassan, M.A.; Wakisaka, M.; Shirai, Y.; Nishida, H. Selective component degradation of oil palm empty fruit bunches (OPEFB) using high-pressure steam. Biomass Bioenerg 2013, 55, 268-275, https://doi.org/10.1016/j.biombioe.2013.02.013.

30. Ming, J. L.; Ming, W. L.; Gunawan, C. and Dale, B. Ammonia fiber expansion (AFEX) pretreatment, enzymatic hydrolysis, and fermentation on empty palm fruit bunch fiber (EFBF) for cellulosic ethanol production. Appl Biochem Biotechnol 2010, 162, 1847-1857, https://doi.org/10.1007/s12010-010-8962-8.

31.Jeon, H.; Kang, K.E.; Jeong, J.S.; Gong, G.; Choi, J.W.; Abimanyu, H.; Ahn, B.S.; Suh, D.J.; Choi, G.W. 2014. Production of anhydrous ethanol using oil palm empty fruit bunch in a pilot plant. Biomass Bioenerg 2014, 67, 99-107, https://doi.org/10.1016/j.biombioe.2014.04.022.

32. Fang, T. W.; Syahindah, N.; Nur Asyikin, S.; Abdul Khalil, H. P. S.; Mohamad Kassim, M. H.; Syakir, M.I. Water absorption and thickness swelling of oil palm empty fruit bunch (OPEFB) and seaweed composite for soil erosion mitigation. J Phys Sci 2017, 28, 1-17, https://doi.org/10.21315/jps2017.28.2.1.

33. Norazlina, A.S.; Che, F.I.; Rosenani, A.B. Characterization of oil palm empty fruit bunch and rice husk biochars and their potential to adsorb arsenic and cadmium. AJABS 2014, 9, 450-456, https://doi.org/10.3844/ajabssp.2014.450.456.

34. Medina, J.D.C.; Woiciechowski, A.; Zandona Filho, A.; Nigam, P.S.; Ramos, L.P.; Soccol, C.R. Steam explosion pretreatment of oil palm empty fruit bunches (EFB) using autocatalytic hydrolysis: A biorefinery approach. Bioresour Technol 2016, 199, 173-180, https://doi.org/10.1016/j.biortech.2015.08.126.

35. Lu, D.; Zhang, X.J. Biogas production from anaerobic codigestion of microalgae and septic sludge. J Environ Eng 2016, 142, 04016049, https://doi.org/10.1061/(ASCE)EE.1943-7870.0001126. 
36. Thambirajah, J.; Zulkali, M.; Hashim, M. Microbiological and biochemical changes during the composting of oil palm empty-fruit-bunches. Effect of nitrogen supplementation on the substrate. Bioresour Technol 1995, 52, 133-144, https://doi.org/10.1016/0960-8524(95)00008-3.

37. Hamdan, A.B.T.; Mohammed Mohd Tayeb, D. Empty fruit bunch mulching and nitrogen fertilizer amendmentthe resultant effect on oil palm performance and soil properties. Oil Palm Bulletin 2006, 52, 48-58.

38. Suhaimi, M.; Ong, H. Composting empty fruit bunches of oil palm. Extension Bulletin-Food \& Fertilizer Technology Center 2001, 505, 1-8.

39. Schuchardt, F.; Darnoko, D.; Guritno, P. Composting of empty oil palm fruit bunch (EFB) with simultaneous evaporation of oil mill waste water (POME). In: 2002 International Oil Palm Conference, Bali, Indonesia. 812 July 2002.

40. KYOTOEnergy.: CDM project 2527: co-composting of EFB and POME project. Project monitoring, July 2009 to July 2010.

41. Kabashi, N.A.; Alam, Z.; Ainuddin, M. Bio-composting process development by SSF for utilization agroindustrial wastes. In: Ibrahim, F.; Abu Osman, N.A.; Usman, J.; Kadri, N.A. (eds.) 3rd Kuala Lumpur International Conference on Biomedical Engineering 2006, 464-468. Springer, Switzerland AG.

42. Siddiqui, Y.; Meon, S.; Ismail, R.; Rahmani, M.; Ali, A. Bio-efficiency of compost extracts on the wet rot incidence, morphological and physiological growth of okra (Abelmoschus esculentus [(L.) Moench]). Sci Hortic 2008, 117, 9-14, https://doi.org/10.1016/j.scienta.2008.03.008.

43. Yahya, A.; Sye, C.P.; Ishola, T.A.; Suryanto, H. Effect of adding palm oil mill decanter cake slurry with regular turning operation on the composting process and quality of compost from oil palm empty fruit bunches. Bioresour Technol 2010, 101, 8736-8741, https://doi.org/10.1016/j.biortech.2010.05.073.

44. Kananam, W.; Suksaroj, T.T.; Suksaroj, C. Biochemical changes during oil palm (Elaeis guineensis) empty fruit bunches composting with decanter sludge and chicken manure. ScienceAsia 2011, 37, 17-23, https://doi.org/10.2306/scienceasia1513-1874.2011.37.017.

45. Amira, R.D.; Roshanida, A.; Rosli, M.; Zahrah, M.S.F.; Anuar, J.M.; Adha, C.N. Bioconversion of empty fruit bunches (EFB) and palm oil mill effluent (POME) into compost using Trichoderma virens. Afr J Biotechnol 2011, 10, 18775-18780, https://doi.org/10.5897/AJB11.2751.

46. Razali, W.A.W.; Baharuddin, A.S.; Talib, A.T.; Sulaiman, A.; Naim, M.N.; Hassan, M.A.; Shirai, Y. Degradation of oil palm empty fruit bunches (EFB) fibre during composting process using in-vessel composter. BioResources 2012, 7, 4786-4805, https://doi.org/10.15376/biores.7.4.4786-4805.

47. Mohammad, N.; Alam, M.Z.; Kabashi, N.A. Development of composting process of oil palm industrial wastes by multi-enzymatic fungal system. J Mater Cycles Waste Manag 2013, 15, 348-356, https://doi.org/10.1007/s10163-013-0125-x.

48. Amira, R.D.; Roshanida, A.; Mohd-Setapar, S.; Rosli, M. Biodegradation of oil palm residues into compost using filamentous fungi. Adv Sci Lett 2013, 19, 3529-3533, https://doi.org/10.1166/asl.2013.5194.

49. Nurliyana, M.; H'ng, P.; Rasmina, H.; Kalsom, M.U.; Chin, K.; Lee, S.; Lum, W.; Khoo, G. Effect of C/N ratio in methane productivity and biodegradability during facultative co-digestion of palm oil mill effluent and empty fruit bunch. Ind Crops Prod 2015, 76, 409-415, https://doi.org/10.1016/j.indcrop.2015.04.047.

50. Siddiquee, S.; Shafawati, S.N.; Naher, L. Effective composting of empty fruit bunches using potential Trichoderma strains. Biotechnol Rep 2017, 13, 1-7, https://doi.org/10.1016/j.btre.2016.11.001.

51. Adeoluwa, O.; Adeoye, G. Potential of oil palm empty fruit bunch (EFB) as fertilizer in oil palm (Elaeis guineensis L Jacq.) nurseries. In: 2nd Conference of the International Society of Organic Agriculture Research ISOFAR, Modena, Italy, June 18-20 2008.

52. Baharuddin, A.S.; Kazunori, N.; Abd-Aziz, S.; Tabatabaei, M.; Rahman, N.A.; Hassan, M.; Wakisaka, M.; Sakai, K.; Shirai, Y. Characteristics and microbial succession in co-composting of oil palm empty fruit bunch and partially treated palm oil mill effluent. Open Biotechnol J 2009, 3, 92-100, https://doi.org/10.2174/1874070700903010087.

53. Ishak, N. F.; Ahmad, A. L.; Ismail, S. Feasibility of anaerobic co-composting empty fruit bunch with activated sludge from palm oil mill wastes for soil conditioner. J Phys Sci 2014, 25, 77-92.

54. Yacob, S.; Devi, S.; Wok, V.; Kumaran, R. The use of bio-compost in oil palm plantation-Sime Darby's experience,

https://www.rt10.rspo.org/ckfinder/userfiles/files/PC8_2\%20Kumaran\%20Rajagopal\%20Abstract.pdf. Accessed 13 March 2020.

55. Ayilara, M.S.; Olanrewaju, O.S.; Babalola, O.O.; Odeyemi, O. Waste management through composting: Challenges and potentials. Sustainability 2020, 12, 4456, https://doi.org/10.3390/su12114456.

56. Palaniveloo, K.; Amran, M.A.; Norhashim, N.A.; Mohamad-Fauzi, N.; Peng-Hui, F.; Hui-Wen, L.; Razak, S.A. Food waste composting and microbial community structure profiling. Processes 2020, 8, 723, https://doi.org/10.3390/pr8060723.

57. Hastuti, P.B.; Rohmiyati, S.M. Application of empty fruit bunches compost and types of P fertilizer on the growth and phosphorus uptake in oil palm seedlings. Agrotech Res $J$ 2020, 4, 59-64, https://doi.org/10.20961/agrotechresj.v4i2.40784. 
58. Alkarimiah, R.; Suja, F. Composting of EFB and POME using a step-feeding strategy in a rotary drum reactor: the effect of active aeration and mixing ratio on composting performance. Pol J Environ Stud 2020, 29, 25432553, https://doi.org/10.15244/pjoes/110518.

59.Hau, L.J.; Shamsuddin, R.; May, A.K.A.; Saenong, A.; Lazim, A.M.; Narasimha, M.; Low, A. Mixed composting of palm oil empty fruit bunch (EFB) and palm oil mill effluent (POME) with various organics: an analysis on final macronutrient content and physical properties. Waste Biomass Valorization 2020, 11, 55395548, https://doi.org/10.1007/s12649-020-00993-8.

60. Yunos, N.S.H.M.; Chu, C.J.; Baharuddin, A.S.; Mokhtar, M.N.; Sulaiman, A.; Rajaeifar, M.A.; Larimi, Y.N.; Talebi, A.F.; Mohammed, M.A.P.; Aghbashlo, M.; Tabatabaei, M. Enhanced oil recovery and lignocellulosic quality from oil palm biomass using combined pretreatment with compressed water and steam. J Clean Prod 2017, 142, 3834-3849, https://doi.org/10.1016/j.jclepro.2016.10.078.

61. Rastogi, M.; Nandal, M.; Khosla, B. Microbes as vital additives for solid waste composting. Heliyon 2020, 6, e03343, https://doi.org/10.1016/j.heliyon.2020.e03343.

62. Sayara, T.; Basheer-Salimia, R.; Hawamde, F.; Sánchez, A. Recycling of organic wastes through composting: Process performance and compost application in agriculture. Agronomy 2020, 10, 1838, https://doi.org/10.3390/agronomy10111838.

63. Kaniapan, S.; Hassan, S.; Ya, H.; Patma Nesan, K.; Azeem, M. The utilisation of palm oil and oil palm residues and the related challenges as a sustainable alternative in biofuel, bioenergy, and transportation sector: A review. Sustainability 2021, 13, 3110, https://doi.org/10.3390/su13063110.

64. Hafyan, R.H.; Bhullar, L.K.; Mahadzir, S.; Bilad, M.R.; Nordin, N.A.H.; Wirzal, M.D.H.; Abdullah, B. Integrated biorefinery of empty fruit bunch from palm oil industries to produce valuable biochemicals. Processes 2020, 8, 868, https://doi.org/10.3390/pr8070868.

65.Padzil, F.N.M.; Lee, S.H.; Ainun, Z.M.A.A.; Lee, C.H.; Abdullah, L.C. Potential of oil palm empty fruit bunch resources in nanocellulose hydrogel production for versatile applications: A review. Materials 2020, 13, 1245, https://doi.org/10.3390/ma13051245. 